\title{
Anatomical Characterization of Nine Taxa of Genus Acmella Rich. (Toothache Plant) in India
}

\author{
Reshmi Geetha Ramachandran ${ }^{1^{*}}$ \\ https://orcid.org/0000-0002-3458-3262
}

Rajalakshmi Radhakrishnan ${ }^{1}$

https://orcid.org/0000-0002-3429-6925

1University Department of Botany, University of Kerala, Kariavattom Campus, Thiruvananthapuram, Kerala, India Received: 2019.02.13; Accepted: 2019.11.25.

* Correspondence: grrechugr@gmail.com; Tel.: +919048088397

\section{HIGHLIGHTS}

- Anatomical characterization of nine taxa of Acmella to supplement data specifically for its current sectional classification and species circumscriptions.

- Anatomical characterization of this genus is little explored.

- Present study narrates the anatomy of stem, leaves, petiole, peduncle and root.

\begin{abstract}
The present study is aimed for anatomical characterization of nine taxa of Acmella to supplement data specifically for its current sectional classification and species circumscriptions. Anatomical characterization of this genus is little explored. This study focuses on internal structure of leaves, petioles, peduncles, stems, roots and cell inclusions to determine its taxonomic importance. In stem anatomy the number of hypodermal collenchymatous layers and the arrangement of parenchymatous cortex together place an important role in the identification of Acmella. Root anatomy was similar in all the examined taxa except in the arrangement of xylem vessels. In A. tetralobata xylem vessels arranged in pentarch fashion while rest of the species possess tetrarch arrangement. Several cellular inclusions such as calcium oxalate crystals and oil bodies were observed. The petioles were crescent shaped having bifacial surfaces with both surfaces pubescent. Peduncles possess ridges and furrows in its outline. The leaves are dorsi ventral and possess single layered epidermal cells covered with cuticle having anomocytic, anisocytic and diacytic types of stomata in both adaxial and abaxial surfaces. The present study provides a tool for the microscopic identification of the genus.
\end{abstract}

Keywords: Asteraceae; Microscopic identification; Micromorphology.

\section{INTRODUCTION}

Anatomical structure provides evidences connecting to the interrelationships of higher taxonomic groups, such as families, sections and tribes and serves to generate true resemblances of genera having indecisive taxonomic status. The differences within species or between groups of less than species rank are usually quantitative rather than qualitative [1]. Anatomy has restricted value for distinguishing them and often demand statistical treatment based on a greater amount of material than generally available [2].

The presence of a well-marked endodermis in the stem is of considerable diagnostic value because of its restricted occurrence. In most dicotyledonous stems the endodermis is not obvious; in some it consists of more or less clearly defined layer of cells which differ from others in containing starch. The presence or absence and nature of the 'pericyclic' sclerenchyma are is of taxonomic value. The position and the average 
number of radial rows of collenchyma cells are valuable for relative anatomical studies in plants $[3,4]$. The arrangement of vascular bundles, distribution, presence or absence of secretory canals are important in the comparative anatomical studies [5]. It was also indicated that the contents and distributions of secretory canals show variation among the Asteraceae members [6]. Despite the importance of anatomical detail in determining the taxonomy of some plant groups, the anatomical characteristics of Acmella have not been fully explored. This is particularly, a genus that requires better infrageneric delimitation. Among the few anatomical studies that are available for this genus, some were restricted to the leaf epidermis [7], while the others focused on the anatomy of the achene [8]. Anatomical features for delimitation at species or generic level are reliable since anatomical features are usually not affected by environmental conditions [9].

The genus Acmella is composed of 30 species and 9 infraspecific taxa [10] and is represented by 9 species and one variety in India $[11,12,13]$. Acmella has a medicinal history dating back to over two millennia and some of its extracts and isolates are of proven efficacy against several diseases [14,15]. The genus is a plant of choice for treating scabies, psoriasis, scurvy and infections of gums. The plant is further recommended as a cure for dysentery and rheumatism, to enhance the immune system and also has antitooth - ache property. Traditionally, it is called as toothache plant. The objective of the present study is to evaluate the anatomical characteristics of the genus Acmella.

\section{MATERIAL AND METHODS}

\section{Plant materials}

Fresh materials of 9 taxa of Acmella; A. calva (De Candolle) R.K. Jansen, A. ciliata (Humboldt, Bonpland \& Kunth) Cassini, A. ghoshinis (Sheela) Reshmi \& Rajalakshmi, A. paniculata (Wallich ex De Candolle) R.K. Jansen, $A$. radicans (Jacquin) R.K. Jansen, $A$. tetralobata (Reshmi \& Rajalakshmi) Reshmi \& Rajalakshmi, $A$. uliginosa (Swartz) Cassini, A. uliginosa var. pentamera Reshmi and Rajalakshmi and $A$. vazhachalensis (Sheela) Reshmi \& Rajalakshmi) were used in this study [16]. Plant materials were collected and identified by comparing with authentic herbarium specimens and descriptions in the flora. Herbarium specimens were prepared and deposited in the Kerala University Botany Herbarium (KUBH), Thiruvananthapuram, Kerala, India. Table 1 shows the collection localities with longitude, latitude and altitude data for each species.

Table 1: Collections of different taxa

\begin{tabular}{lccc}
\hline \multicolumn{1}{c}{ Taxa } & Collection location & Longitude and Latitude & Altitude (m) \\
\hline A. calva & Ponmudi & $8^{\circ} 45^{\prime} 35.7912^{\prime \prime} \mathrm{N} 77^{\circ} 7^{\prime}$ 0.75" E & 914.60 \\
A. ciliata & Karamana & $8^{\circ} 28^{\prime} 54.4116^{\prime \prime} \mathrm{N} 76^{\circ} 57^{\prime} 56.6856^{\prime \prime} \mathrm{E}$ & 25.217 \\
A. ghoshinis & Kottayam & $9^{\circ} 35^{\prime} 29.6412^{\prime \prime} \mathrm{N} 76^{\circ} 31^{\prime} 19.7508^{\prime \prime} \mathrm{E}$ & 27.325 \\
A. radicans & Koothattukulam & $9^{\circ} 51^{\prime} 45.7488^{\prime \prime} \mathrm{N} 76^{\circ} 35^{\prime} 39.1848^{\prime \prime} \mathrm{E}$ & 34.859 \\
A. paniculata & Vagamaon,ID & $9^{\circ} 41^{\prime} 10.2516^{\prime \prime} \mathrm{N} 76^{\circ} 54^{\prime} 18.8244^{\prime \prime} \mathrm{E}$ & 1005.33 \\
A. tetralobata & Puliyoor, Alappuzha & $9^{\circ} 18^{\prime} 10.3032^{\prime \prime} \mathrm{N} 76^{\circ} 35^{\prime} 10.9968^{\prime \prime} \mathrm{E}$ & 11.310 \\
A. uliginosa & Neyyattinkara & $8^{\circ} 24^{\prime} 5.9328^{\prime \prime} \mathrm{N} 77^{\circ} 5^{\prime} 13.632^{\prime \prime} \mathrm{E}$ & 26.165 \\
A. uliginosa var. pentamera & Bhudhanoor, & $9^{\circ} 18^{\prime} 26.6436 " \mathrm{~N} 76^{\circ} 33^{\prime} 47.7828^{\prime \prime} \mathrm{E}$ & 8.157 \\
A. vazhachalensis & Alappuzha & & \\
\hline
\end{tabular}

\section{Anatomical Sectioning}

Cylindrical portions of the stem, petiole, peduncle, root and midribs from the basal part of the leaf lamina were cut with the help of razor blade in transverse view. All the fine sections were stained with $1 \%$ aqueous safranin for 3 minutes and mounted in 50\% glycerine to prepare temporary mounts for observations, micro-photography and quantitative measurements. Interesting observations were recorded using the Leica microscope with Leica DFC 425C image analyzer software.

\section{Tissue preparation and examination of oil cells}

Hand-cut sections were prepared from fresh leaves and incubated in Schiff's reagent (Sigma, USA) at room temperature. The sections were then washed three times (10 min each) with a freshly prepared solution 
of $5 \%(\mathrm{w} / \mathrm{v})$ sodium meta bisulphite in $1 \% \mathrm{HCl}$ [17] and examined under Leica microscope with Leica DFC $425 \mathrm{C}$ image analyzer software.

\section{Histochemical localization}

Starch

Sections of the sample were placed in iodine-potassium $(0.2 \mathrm{~g}$ of iodine dissolved in $2 \%$ potassium iodide solution) for two minutes and rinsed in distilled water. They were then mounted in glycerine jelly, observed and photographed. Starch grains appeared blue black [18].

\section{Total Proteins}

Sections of the materials were immersed in the dye solution $(10 \mathrm{~g}$ of mercuric chloride and $100 \mathrm{mg}$ of bromo phenol blue dissolved in $100 \mathrm{ml}$ of water) for $15 \mathrm{~min}$. The sections were then washed in $0.5 \%$ acetic acid for 20 min to remove the excess dye. They were then washed in water for 15 minutes and mounted in glycerin jelly, observed and photographed. Proteins stain blue [19].

\section{Lipids}

Sections of the material were pre treated with $70 \%$ ethanol for $1-2$ min and stained in a freshly filtered solutionof Sudan Black Bat $600 \mathrm{C}$ for one hour. The sections were then rinsed in $70 \%$ ethanol for $1 \mathrm{~min}$, washed in water, dried and mounted in glycerine jelly, observed and photographed. Lipids are stained black. Standard control procedures were carried out simultaneously [20].

\section{RESULTS}

\section{Stem anatomy}

A single cell layered, cuticularised epidermis forms the outermost layer of the stem with multicellular hairs as an outgrowth of epidermal cells. A collenchymatous hypodermis lies beneath the epidermis. It encircles the cortex which is two cells wide in $A$. calva, $A$. paniculata, $A$. uliginosa and $A$. uliginosa var. pentamera; three cells layered in $A$. ciliata, $A$. ghoshinis and $A$. vazhachalensis while four cells wide in $A$. radicans and $A$. tetralobata. The cortex comprised of 4-5 cell wide layer of loosely arranged oval to polygonal parenchymatous cells in $A$. calva, $A$. ciliata and $A$. ghoshinis. In contrast, cortical cells were tightly packed in $A$. radicans while it was aerenchymatous in nature in. $A$. paniculata, $A$. tetralobata, $A$. uliginosa, $A$. uliginosa var. pentamera and $A$. vazhachalensis. The number of hypodermal collenchymatous layers and the arrangement of parenchymatous cortex together place an important role in the identification of Acmella. Endodermis lies on the inner margin of cortex and it was composed of barrel shaped cells. Below the endodermis pericycle was present which consisted of alternate bands of parenchymatous and sclerenchymatous cells (Figure 1,2,3).

In the young stems, 13-18 variously sized conjoint and collateral vascular bundles were arranged in the form of a complete ring in all the species except $A$. ghoshinis. A. ghoshinis shows bicollateral vascular bundles (Figure 1). Pith occupies the centre and is composed of parenchymatous cells. It shows various internal secretory cells such as secretory idioblast cells, oil granules, mucosal cells, starch grains, and inulin crystals in all the species (Figure 9). Secretory canals were noticed in all the species investigated. In $A$. ciliata they were very large and prominent while very small in $A$. tetralobata. Trichomes were seen in all the species. Unicellular trichomes were observed in leaves, whereas multicellular with long pointed in petioles (Figure 10).

\section{Petiole anatomy}

The cross sections of petiole were crescent shaped structure with concave surface on the adaxial side and convex in the abaxial. The structure was bifacial with both surfaces pubescent. The epidermal cells of both surfaces were arranged in a single layer, covered by a thin cuticle and broken by the presence of stomata and non-glandular hairs. Below the epidermis is the hypodermis composed of 1-2 layers of collenchyma cells followed by a number of parenchymatous cells, constituting the inner cortex. The number of vascular bundles varied from 4-7 in which three vascular bundles were larger than the rest in all the species. 
(Figure 4) No significant differences were noticed in the petiolar anatomy within the species except in the number of cortical layers and vascular bundles.

\section{Peduncle anatomy}

The peduncle has almost similar anatomical structure with that of stem except in possessing ridges and furrows in the outline. Epidermis is followed by collenchymatous hypodermis, parenchymatous cortex and endodermis. Significant variations were not observed in inter and intraspecific levels. The vascular bundles were conjoint, collateral and open and were arranged in the form of a ring followed by parenchymatous pith (Figure 5). No significant differences were noticed in the peduncle anatomy within the species.

\section{Leaf anatomy}

Anatomically, leaf structure of all the species remains similar. In all the species, leaves are dorsi ventral and possess single layered epidermal cells covered with cuticle. Mesophyll tissue lies between the upper and lower epidermis. Three different types of stomata were noticed in the leaves of each species. All the species possessed anomocytic, anisocytic and diacytic types of stomata in both adaxial and abaxial surfaces (Figure 11). Palisade parenchyma cells were columnar vertically elongated and perpendicular to the upper epidermis. Palisade cells were mostly arranged in two layers without any intercellular spaces. Spongy parenchyma cells were oval to polygonal in shape containing chloroplasts. They were loosely arranged with intercellular spaces. Collateral vascular bundles are found scattered throughout the spongy parenchyma. The mid rib region consists of cuticularised single layered round celled upper and lower epidermis and is followed by 1-2 layers of collenchymatous cells. Each mid rib region contained a large vascular bundle with xylem having 110-140 $\mu \mathrm{m}$ in size and phloem consisting of dense sclerenchymatous fibers measuring 90-110 $\mu \mathrm{m}$ length (Figure 6). Multicellular non glandular hairs were observed on both sides of the epidermis.

\section{Root anatomy}

The outermost layer is epiblema and these cells usually have fine tubular elongations called root hairs. Cortex extends below the epiblema up to the endodermis. It is composed of circular to polygonal parenchymatous cells with intercellular spaces. A single layered endodermis encircles the pericycle. On the inner margin of the pericycle several radial vascular bundles were arranged in a ring. Xylem was exarch, and show pentarch xylem in $A$. tetralobata while it was tetrarch in rest of the species. Pith is poorly developed due to the extension of meta xylem towards the centre (Figure 7,8). Starch grain depositions were observed in the cortex regions in all the species during secondary growth (Figure 9).

Given figures represent the common internal organisation of leaf, petiole, peduncle and trichome of Acmella. Table 2 shows the characteristic anatomical differences between the species.

\section{Oil cells}

Oil cells filled with oil granules were observed in all the leaves of species under study. This suggests the presence of essential oil in all the species (Figure 12).

\section{Histochemical localization}

Histochemical analysis confirmed the presence of starch, lipids and proteins in all the nine taxa studied. Given figures represent only a single species (Figure 13)

Histochemical localization procedures showed the presence of certain chemical components such as lipid bodies, starch grains, oil granules, protein bodies. Histochemistry also revealed the presence of some ergastic substances such as Calcium oxalate crystals in the form of druses and styloid crystals. Secretory idioblast cells, secretory canals, lipid bodies, starch grains, oil granules and protein bodies were observed in all the studied species. Calcium oxalate crystals such as druses and Styloid crystals were observed. Druses absent in $A$. uliginosa Var. pentamera and $A$. paniculata. Styloid crystals were found only in $A$. tetralobata, $A$. radicans and $A$. uliginosa(Figure 14). Anthocyanin pigments were observed in $A$. ghoshinis, $A$. radicans, $A$. tetralobata and $A$. uliginosa. Presence of starch, proteins and lipids were also confirmed in all the studied species. Table 3 shows the presence or absence of secretory and ergastic substances in the nine taxa studied. 
Table 2: Characteristic anatomical differences between the species

\begin{tabular}{|c|c|c|c|c|c|c|}
\hline \multirow{2}{*}{ Species } & \multicolumn{4}{|c|}{ Stem anatomy } & \multirow{2}{*}{$\begin{array}{c}\text { Petiole } \\
\text { anatomy } \\
\text { Shape }\end{array}$} & \multirow{2}{*}{$\begin{array}{c}\text { Root anatomy } \\
\text { Xylem }\end{array}$} \\
\hline & $\begin{array}{l}\text { No. of hypo } \\
\text { dermal layer }\end{array}$ & cortex & $\begin{array}{l}\text { Vascular } \\
\text { Bundles }\end{array}$ & $\begin{array}{l}\text { Secretory } \\
\text { canals }\end{array}$ & & \\
\hline A. calva & Two & $\begin{array}{l}\text { 4-5 cell wide layer of loosely arranged oval } \\
\text { to polygonal parenchymatous cells }\end{array}$ & Collateral & medium sized & crescent & tetrarch \\
\hline A. ciliata & Three & $\begin{array}{l}\text { 4-5 cell wide layer of loosely arranged oval } \\
\text { to polygonal parenchymatous cells }\end{array}$ & Collateral & $\begin{array}{l}\text { very large and } \\
\text { prominent }\end{array}$ & crescent & tetrarch \\
\hline A. ghoshinis & Three & $\begin{array}{l}\text { 4-5 cell wide layer of loosely arranged oval } \\
\text { to polygonal parenchymatous cells }\end{array}$ & Bicollateral & medium sized & crescent & tetrarch \\
\hline A. radicans & Four & tightly packed & Collateral & medium sized & crescent & tetrarch \\
\hline A. paniculata & two & aerenchymatous & Collateral & medium sized & crescent & tetrarch \\
\hline A. tetralobata & Four & aerenchymatous & Collateral & very small & crescent & pentarch \\
\hline A. uliginosa & Two & aerenchymatous & Collateral & medium sized & crescent & tetrarch \\
\hline A. uliginosa var. pentamera & Two & aerenchymatous & Collateral & medium sized & crescent & tetrarch \\
\hline A. vazhachalensis & Three & aerenchymatous & Collateral & medium sized & crescent & tetrarch \\
\hline
\end{tabular}


Table 3: Showing the presence or absence of secretory substances and ergastic substances

\begin{tabular}{|c|c|c|c|c|c|c|c|c|c|c|}
\hline Species & $\begin{array}{c}\text { Secretory } \\
\text { idioblast } \\
\text { cells }\end{array}$ & $\begin{array}{c}\text { Secretory } \\
\text { Canal }\end{array}$ & $\begin{array}{l}\text { Lipid } \\
\text { bodies }\end{array}$ & $\begin{array}{l}\text { Starch } \\
\text { grains }\end{array}$ & Druse & $\begin{array}{c}\text { Oil } \\
\text { granules }\end{array}$ & $\begin{array}{c}\text { Anthocyanin } \\
\text { pigments }\end{array}$ & $\begin{array}{l}\text { Styloid } \\
\text { crystals }\end{array}$ & $\begin{array}{l}\text { Protein } \\
\text { bodies }\end{array}$ & $\begin{array}{l}\text { Calcium } \\
\text { oxalate } \\
\text { crystals }\end{array}$ \\
\hline A. calva & $\checkmark$ & $\checkmark$ & $\checkmark$ & $\checkmark$ & $\checkmark$ & $\checkmark$ & $X$ & $X$ & $\checkmark$ & $\checkmark$ \\
\hline A. ciliata & $\checkmark$ & $\checkmark$ & $\checkmark$ & $\checkmark$ & $\checkmark$ & $\checkmark$ & $X$ & $X$ & $\checkmark$ & $\checkmark$ \\
\hline A. ghoshinis & $\checkmark$ & $\checkmark$ & $\checkmark$ & $\checkmark$ & $\checkmark$ & $\checkmark$ & $\checkmark$ & $X$ & $\checkmark$ & $\checkmark$ \\
\hline A. radicans & $\checkmark$ & $\checkmark$ & $\checkmark$ & $\checkmark$ & $\checkmark$ & $\checkmark$ & $\checkmark$ & $X$ & $\checkmark$ & $\checkmark$ \\
\hline A. paniculata & $\checkmark$ & $\checkmark$ & $\checkmark$ & $\checkmark$ & $X$ & $\checkmark$ & $X$ & $X$ & $\checkmark$ & $X$ \\
\hline A. tetralobata & $\checkmark$ & $\checkmark$ & $\checkmark$ & $\checkmark$ & $\checkmark$ & $\checkmark$ & $\checkmark$ & $\checkmark$ & $\checkmark$ & $\checkmark$ \\
\hline A. uliginosa & $\checkmark$ & $\checkmark$ & $\checkmark$ & $\checkmark$ & $\checkmark$ & $\checkmark$ & $\checkmark$ & $X$ & $\checkmark$ & $\checkmark$ \\
\hline A. uliginosa var. pentamera & $\checkmark$ & $\checkmark$ & $\checkmark$ & $\checkmark$ & $X$ & $\checkmark$ & $X$ & $X$ & $\checkmark$ & $X$ \\
\hline A. vazhachalensis & $\checkmark$ & $\checkmark$ & $\checkmark$ & $\checkmark$ & $\checkmark$ & $\checkmark$ & $X$ & $\checkmark$ & $\checkmark$ & $\checkmark$ \\
\hline
\end{tabular}




\section{Figures}
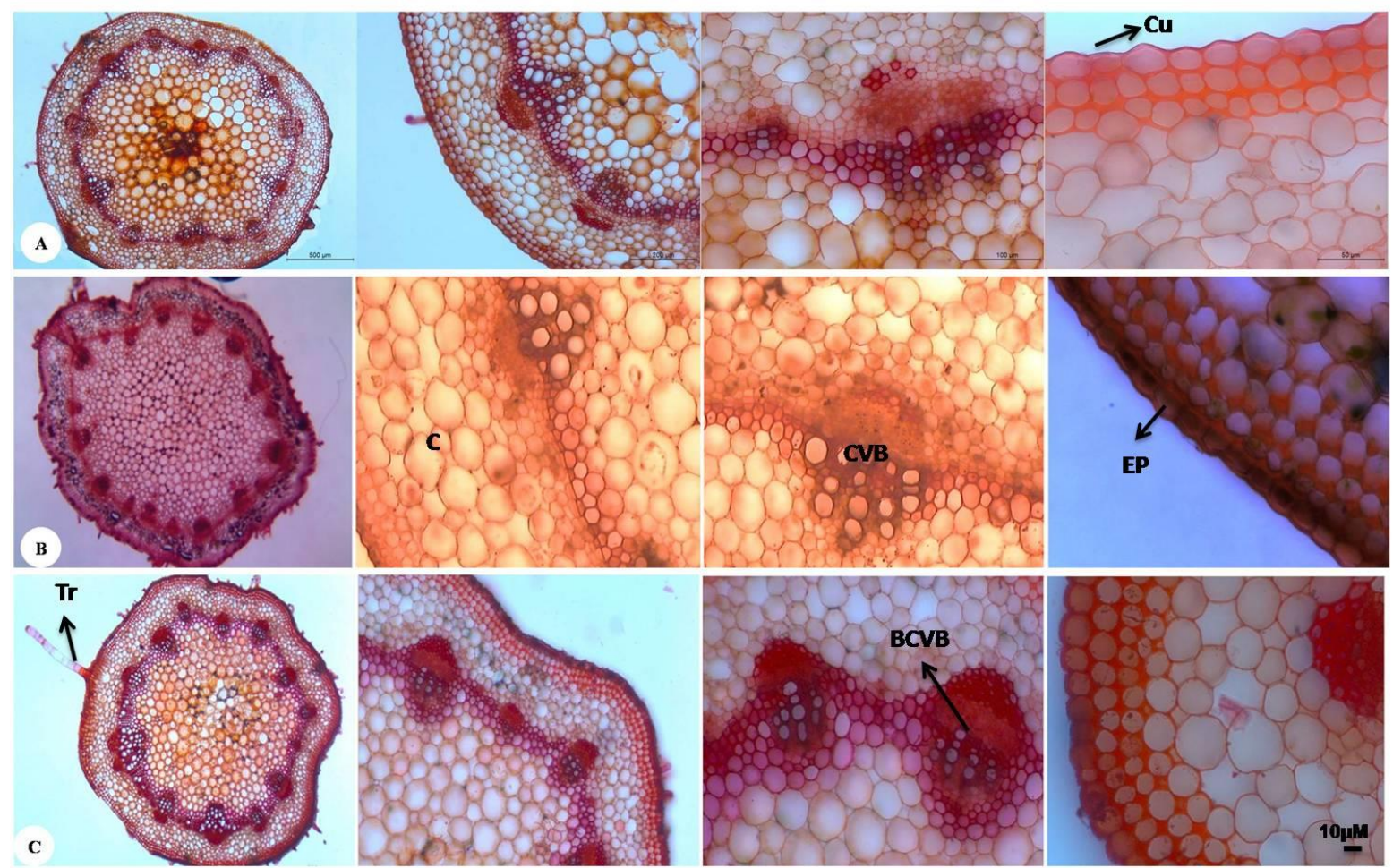

Figure 1. Stem anatomy A) A. calva showing whole section; epidermis, cortex and vascular bundles; vascularbundle portion enlarged; epidermal portion enlarged B) $A$. ciliata showing whole section, epidermis, cortexand vascular bundles; vascular bundle portion enlarged ; epidermal portion enlarged C) A. ghoshinis showing whole section; epidermis, cortex and vascular bundles; vascular bundle portion enlarged; epidermalportion enlarged Cu- Cuticle; HP- Hypodermis; C- Cortex; CVB- Collateral vascular bundle; BCVBBicollateral vascular bundle; Tr- Trichome, Scale bar $=10 \mu \mathrm{M}$

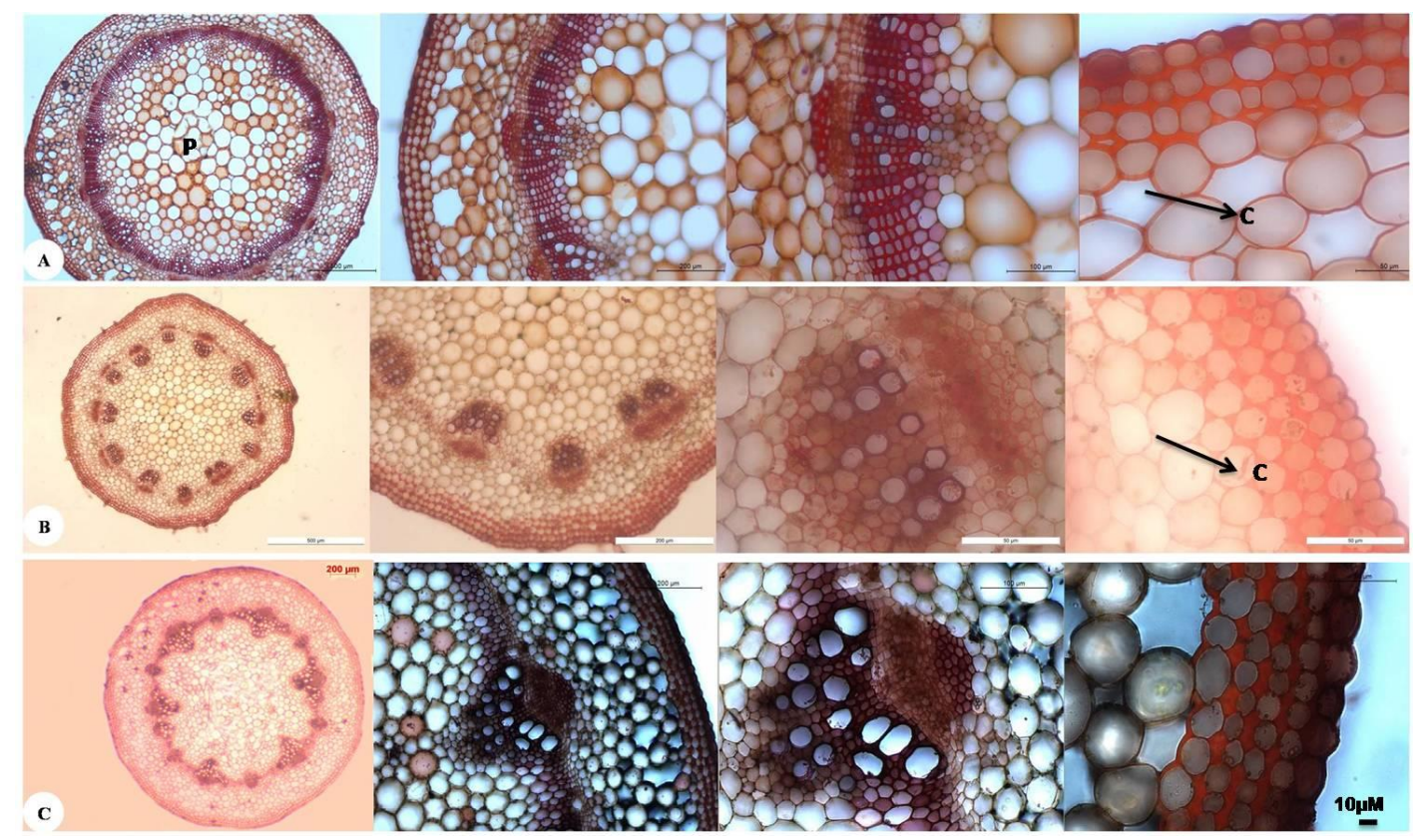

Figure 2. Stem anatomy A) A. paniculata showing whole section; epidermis, cortex and vascular bundles; vascular bundle portion enlarged; epidermal portion enlarged B) A. radicans showing whole section; epidermis, cortex and vascular bundles; vascular bundle portion enlarged; epidermal portion enlarged C) $A$. tetralobata showing whole section; epidermis, cortex and vascular bundles; vascular bundle portion enlarged; Epidermal portion enlarged P- Pith; C- Cortex; Scale bar=10 $\mu \mathrm{M}$ 

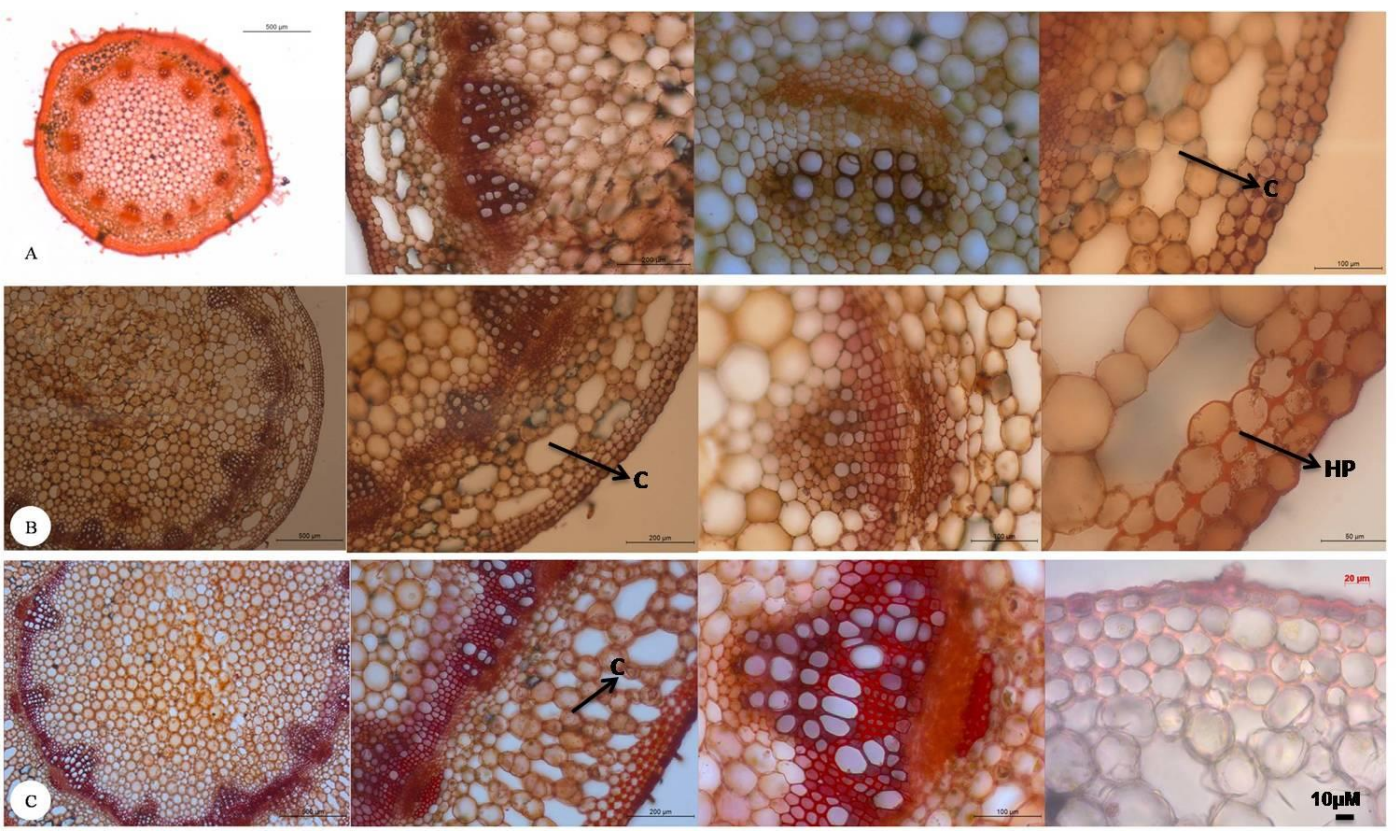

Figure 3. Stem anatomyA) A. uliginosa showing whole section; epidermis, cortex and vascular bundles;vascular bundle portion enlarged; epidermal portion enlarged B) $A$. uliginosa var. pentamera whole section;epidermis, cortex and vascular bundles; vascular bundle portion enlarged; epidermal portion enlarged C) A. vazhachalensis whole section; epidermis, cortex and vascular bundles; vascular bundle portion enlarged;epidermal portion enlarged C- Cortex; HP- Hypodermis; Scale bar=10 $\mu \mathrm{M}$
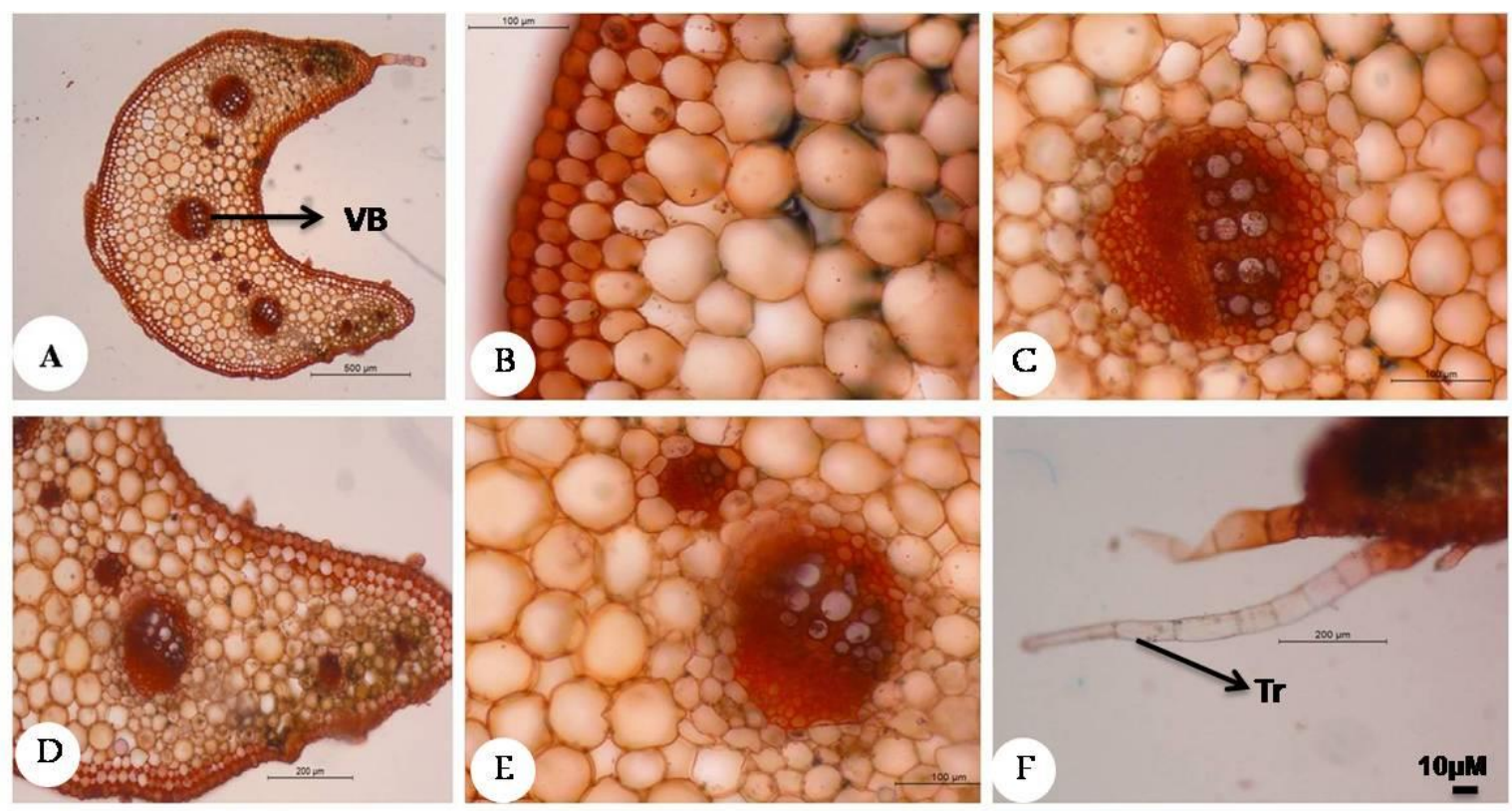

Figure 4. Anatomy of petiole of $A$. tetralobataA) Whole section B) Showing epidermis and cortex C) Portionenlarged showing vascular bundles D) Portion enlarged showing vascular bundles and epidermis E) Showingsmaller and larger vascular bundles F) Showing trichomes VB- Vascular bundle; Tr- Trichome; Scale bar $=10 \mu \mathrm{M}$ 


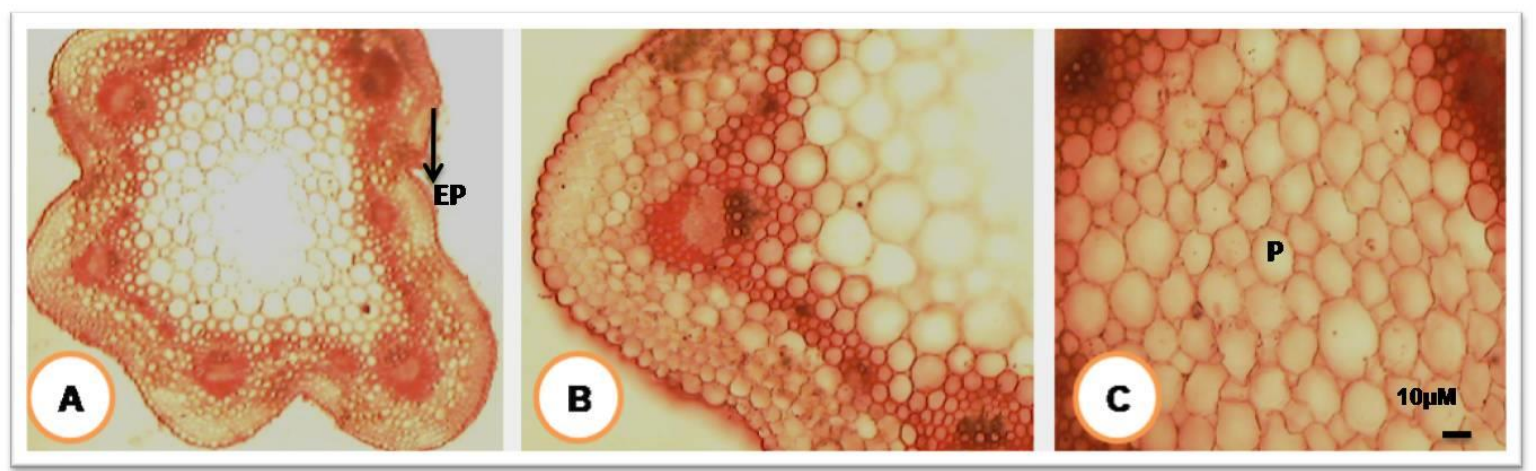

Figure 5. Anatomy of peduncle of $A$. ciliateA) Whole section B) Showing epidermis, cortex and vascular bundlesC) Portion enlarged showing pith Ep- Epidermis; P- Pith; Scale bar=10 $\mu \mathrm{M}$

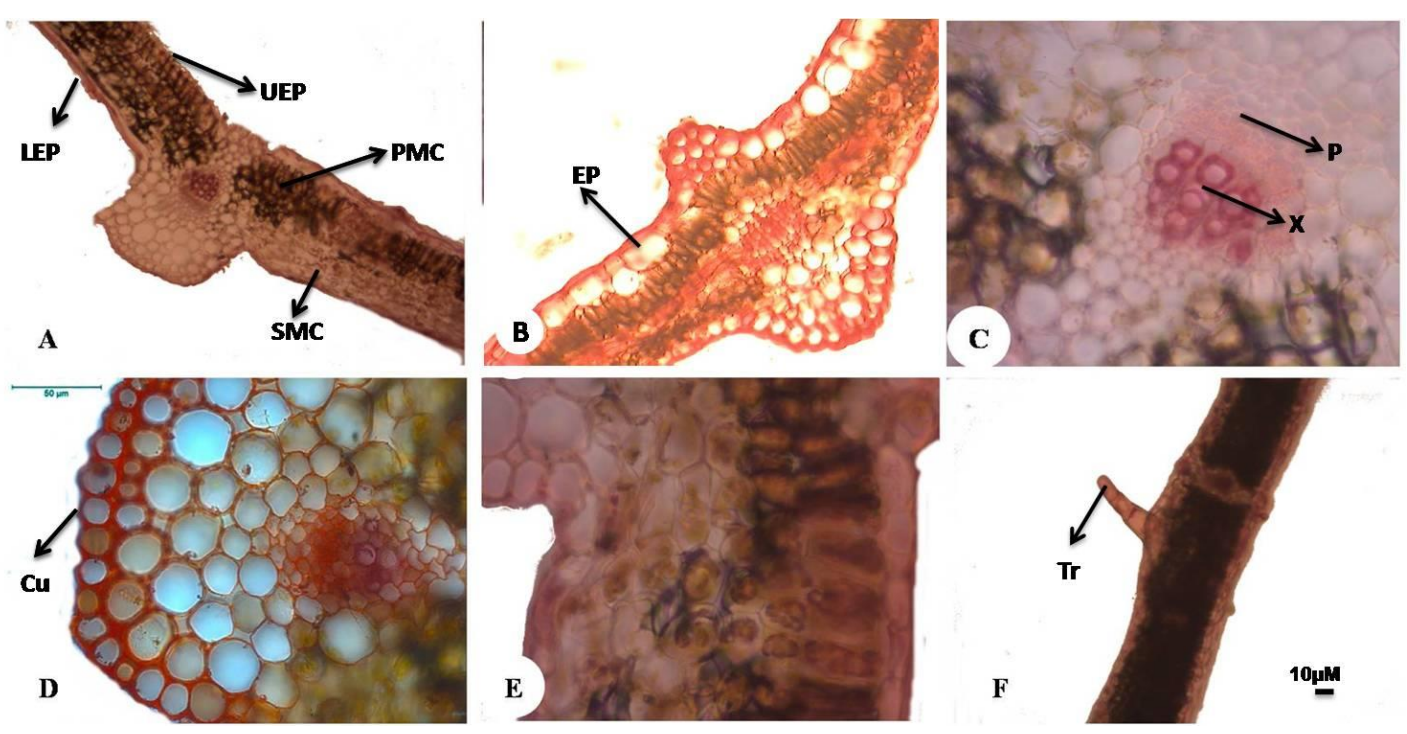

Figure 6. Anatomy of leaf of $A$. ciliateA-B) Whole section showing epidermis C) Portion enlarged showingvascular bundles D) Portion enlarged showing vascular bundles and epidermis E) Showing palisadeparenchyma and spongy parenchyma F) Trichome LEP- Lower epidermis; UEP- Upper epidermis; PMC- PalisadeMesophyll Cells; SMC- Spongy Mesophyll Cells; Cu- Cuticle; Tr- Trichome; P- Phloem; XXylem;Scale bar $=10 \mu \mathrm{M}$ 

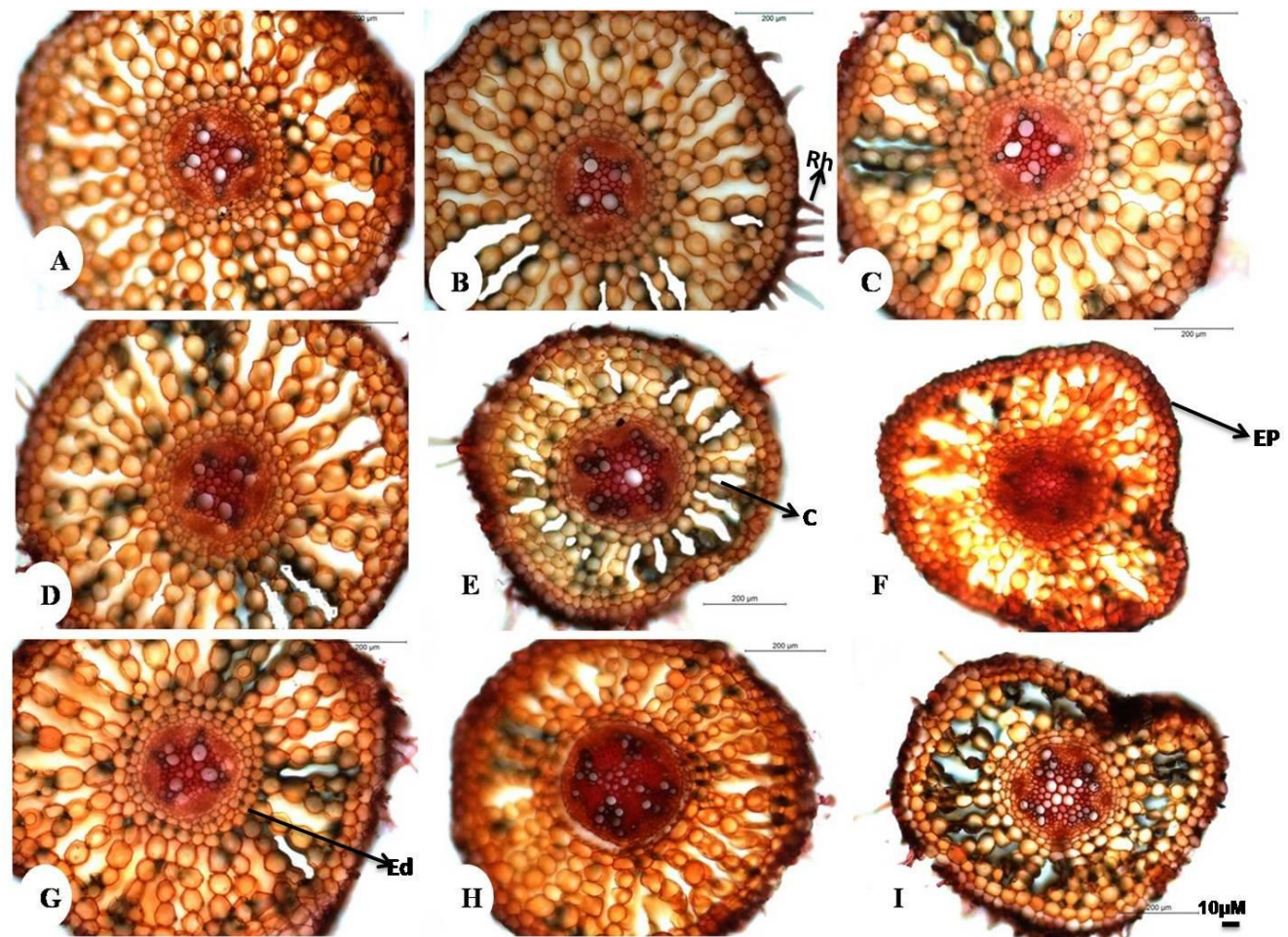

Figure 7. Root anatomy of AcmellaA) A. calva B) A. ciliata C) A. ghoshinis D) A. paniculata E) A. radicans F) A. tetralobata G) A. uliginosa H) A. uliginosa var. pentamera I) A. vazhachalensis Rh- Root hair; EPEpidermis; C- Cortex; Ed- Endodermis; Scale bar $=10 \mu \mathrm{M}$
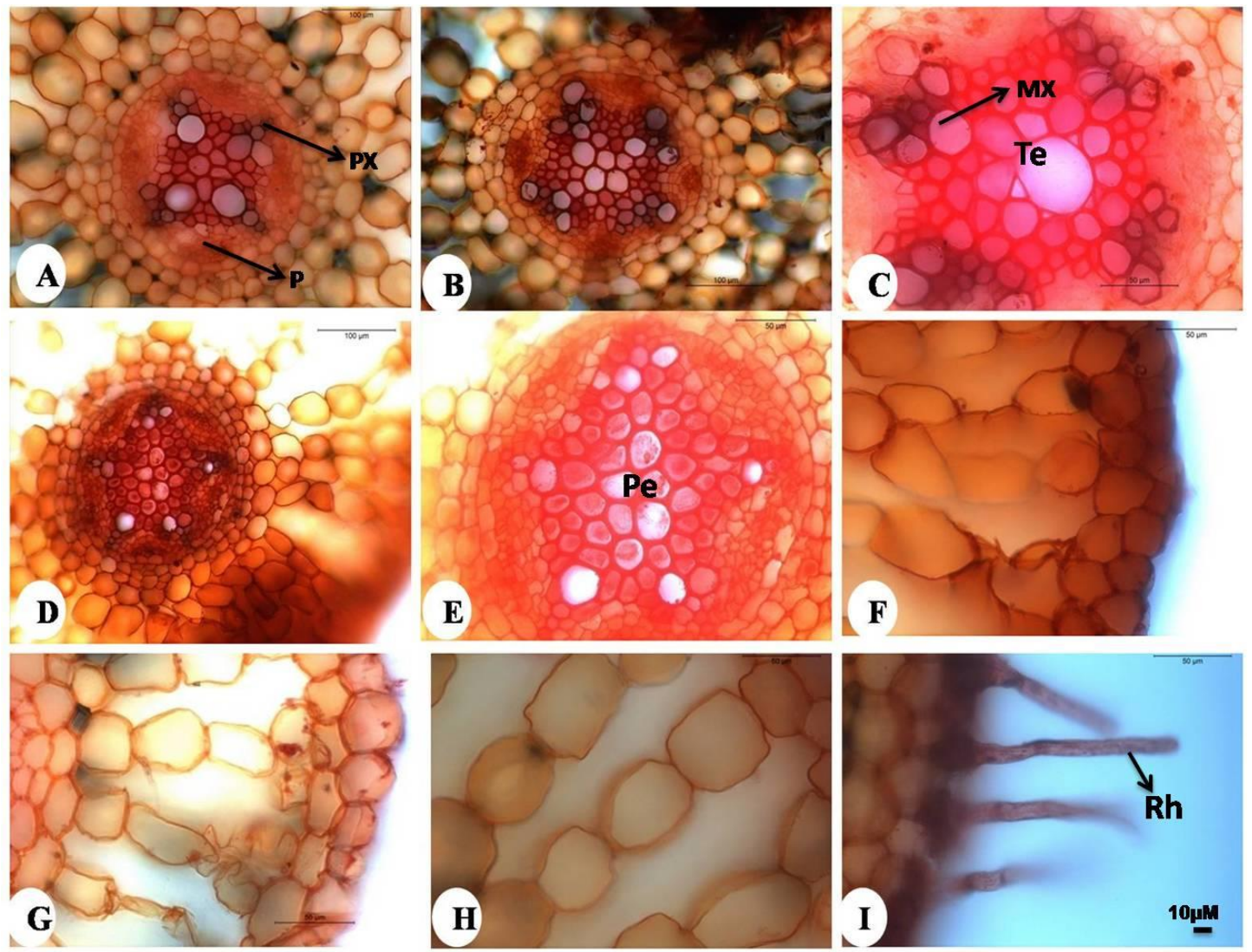

Figure 8. Root anatomy of Acmella showing variationsA-C) Enlarged image showing tetrarch vascular bundlesD-E) Enlarged image showing pentarch vascular bundles in A. tetralobata F-G) Enlarged image showingcortex and pith H) Cortex showing tubular cells I) Root hairs P- Phloem; PX- Proto xylem; MXMetaxylem;Te- Tetrach; Pe- Pentarch; Rh- Root hair;Scale bar=10 $\mu \mathrm{M}$ 


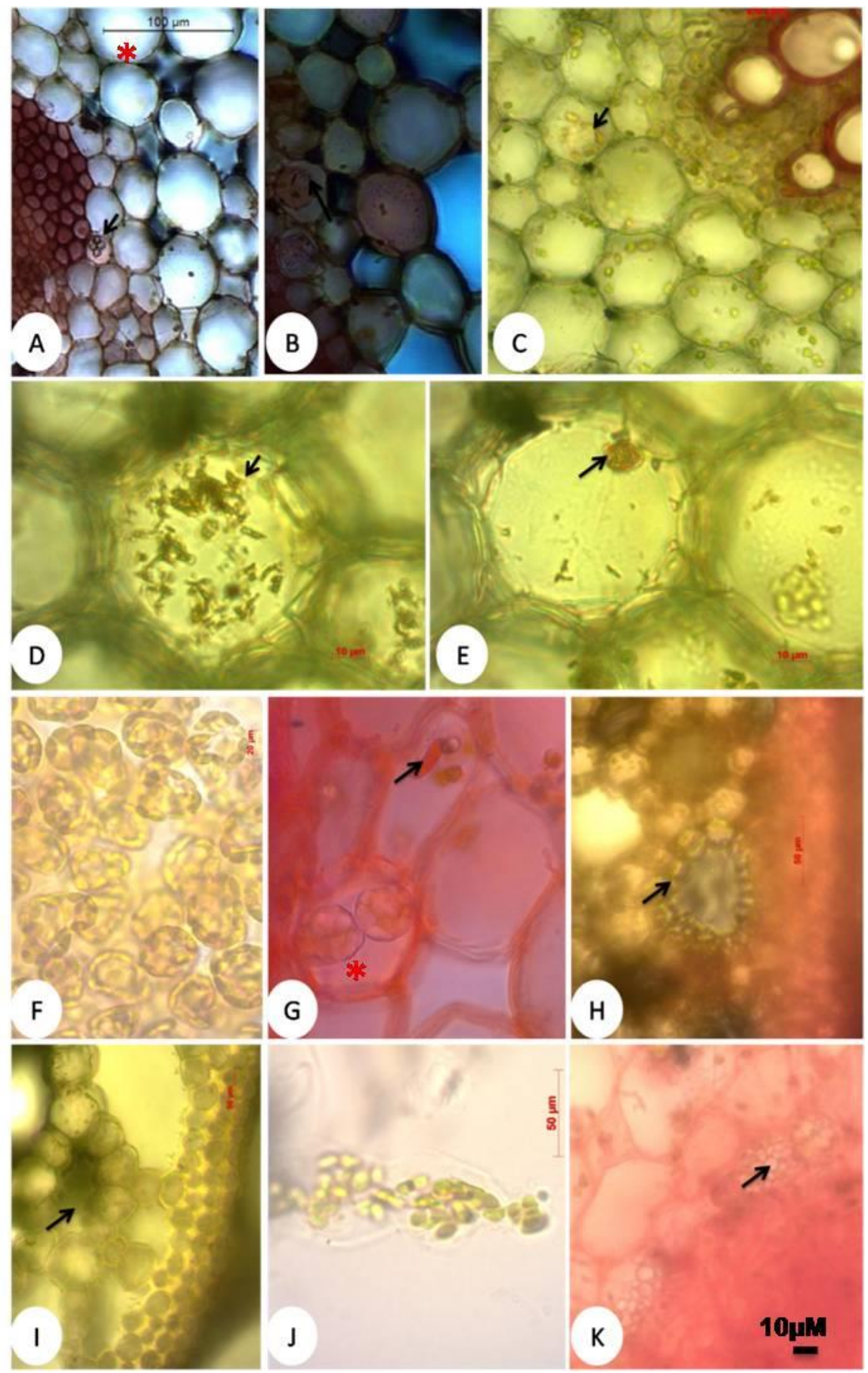

Figure 9. Cellular secretions and ergastic deposits in AcmellaA) Secretory idioblast cells (long arrow), secretory canal (*) B) Lipid bodies (Arrow) C) starch grains (Arrow) D) Calcium oxalate crystals (Arrow) E)Druse (Arrow) F) Oil granules G) Anthocyanin pigments $\left(^{*}\right)$, Styloid crystals (Arrow) H) Secreting canal(Arrow) I) Idioblast cell filled with tannin (Arrow) J) Oil granules K) Protein bodies (Arrow) Scale bar $=10 \mu \mathrm{M}$ 

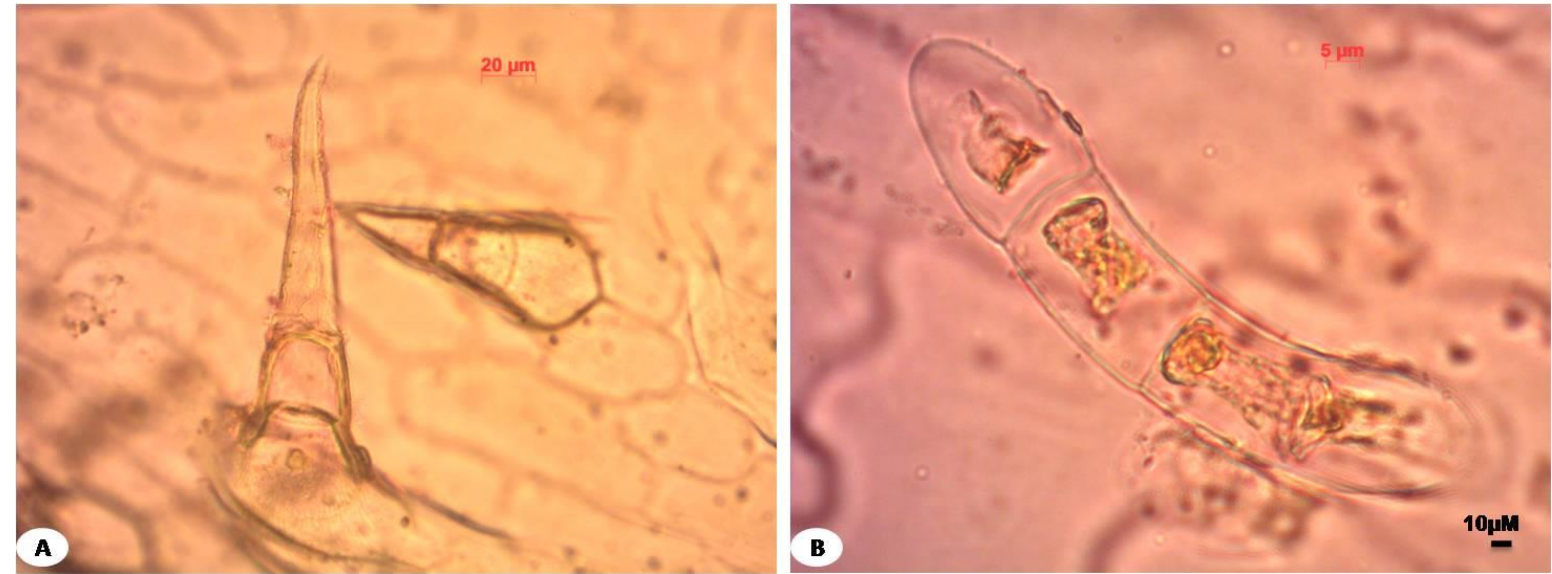

Figure 10. TrichomesA) Unicellular non glandular trichome B) Multicellular non glandular trichome Scale bar=10 $\mu \mathrm{M}$

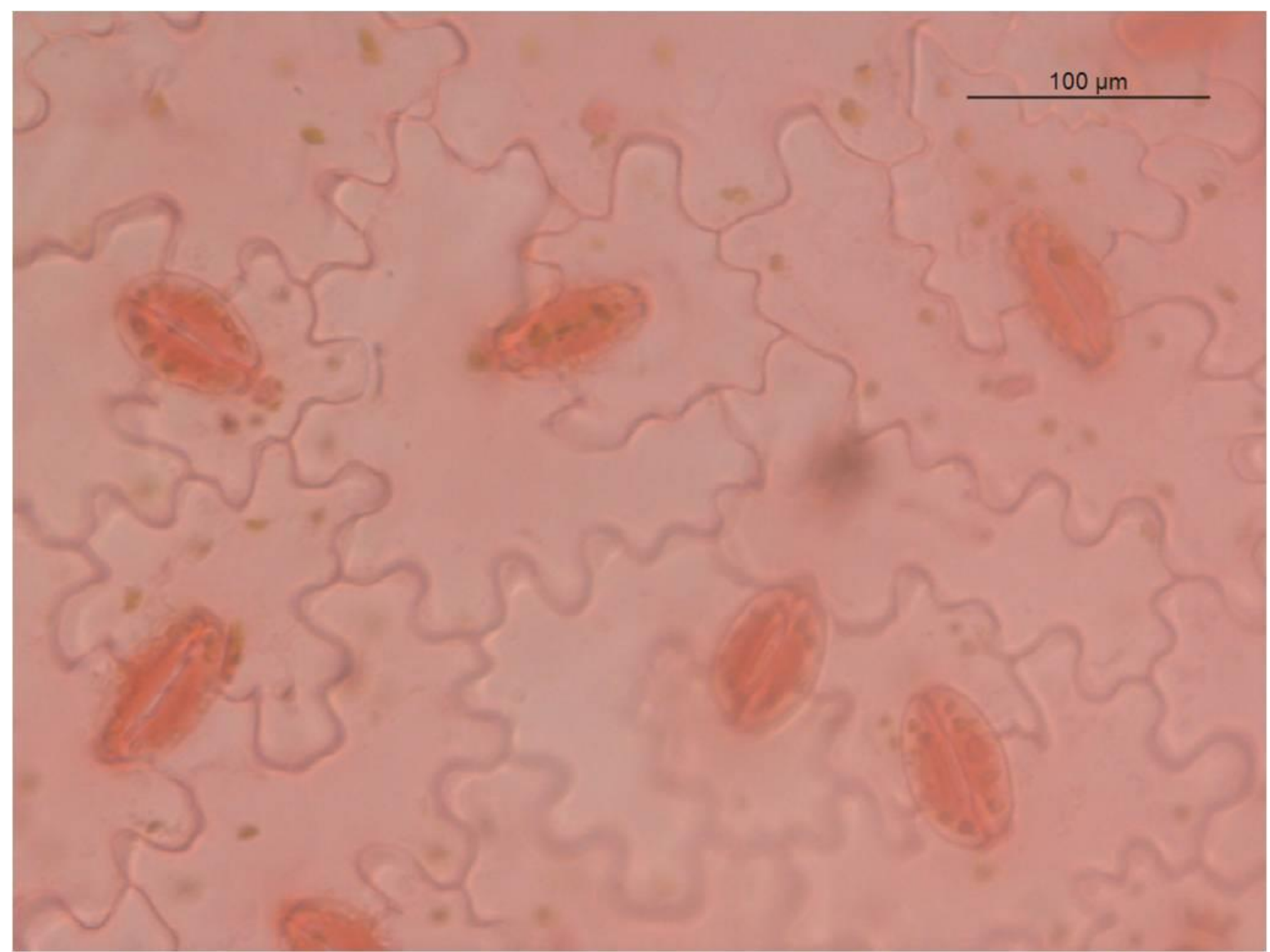

Figure 11. Stomata in $A$. radicans showing diacytic, anisocytic, anomocytic and abnormal stomata sharingsubsidiary cell SC- subsidiary cell; EC- Epidermal cell; GC- Guard cell; S- Stoma; Scale bar=100 $\mu \mathrm{M}$ 


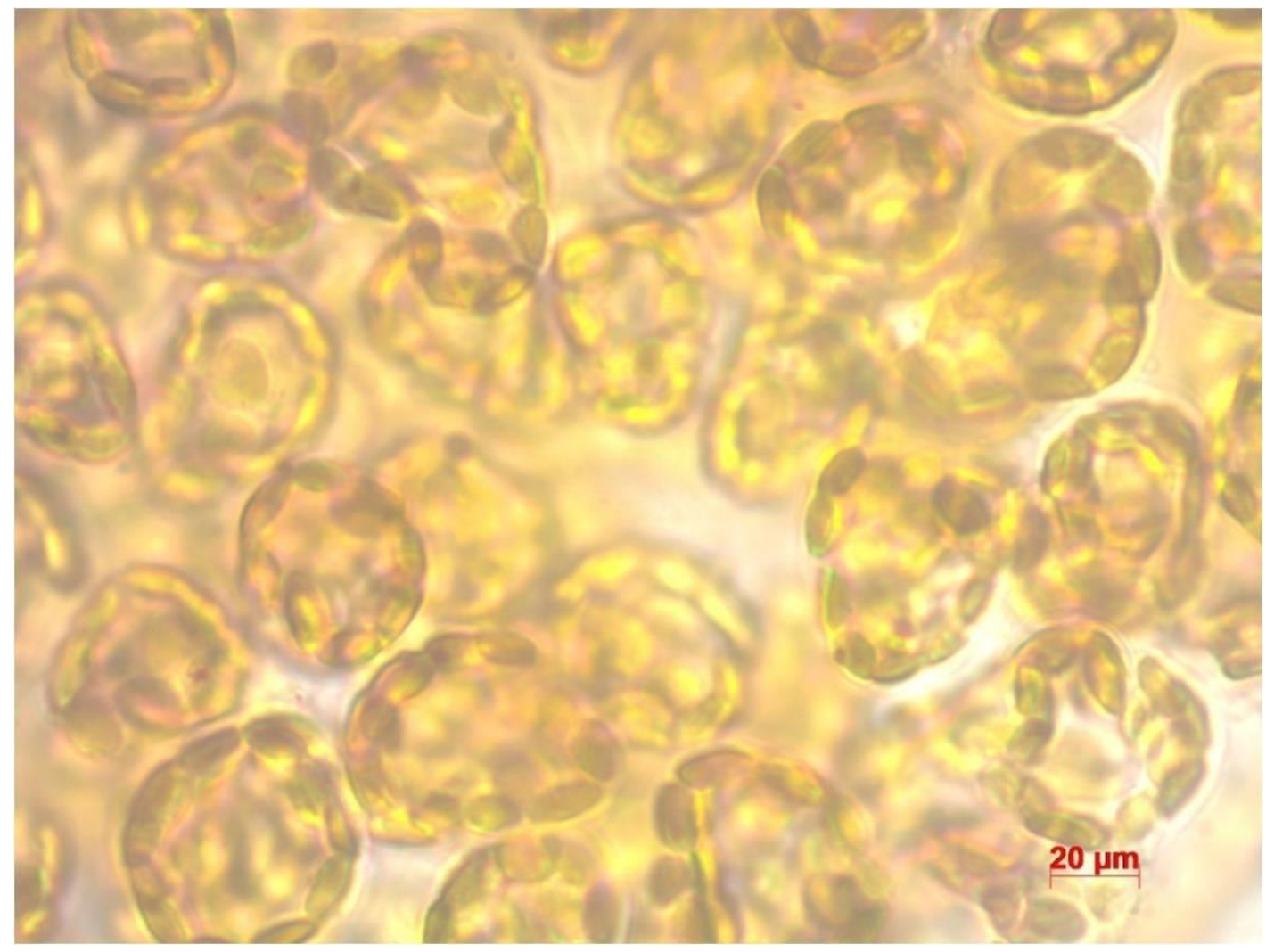

Figure 12. Oil cells in $A$. ciliata showing oil granules; Scale bar $=20 \mu \mathrm{M}$
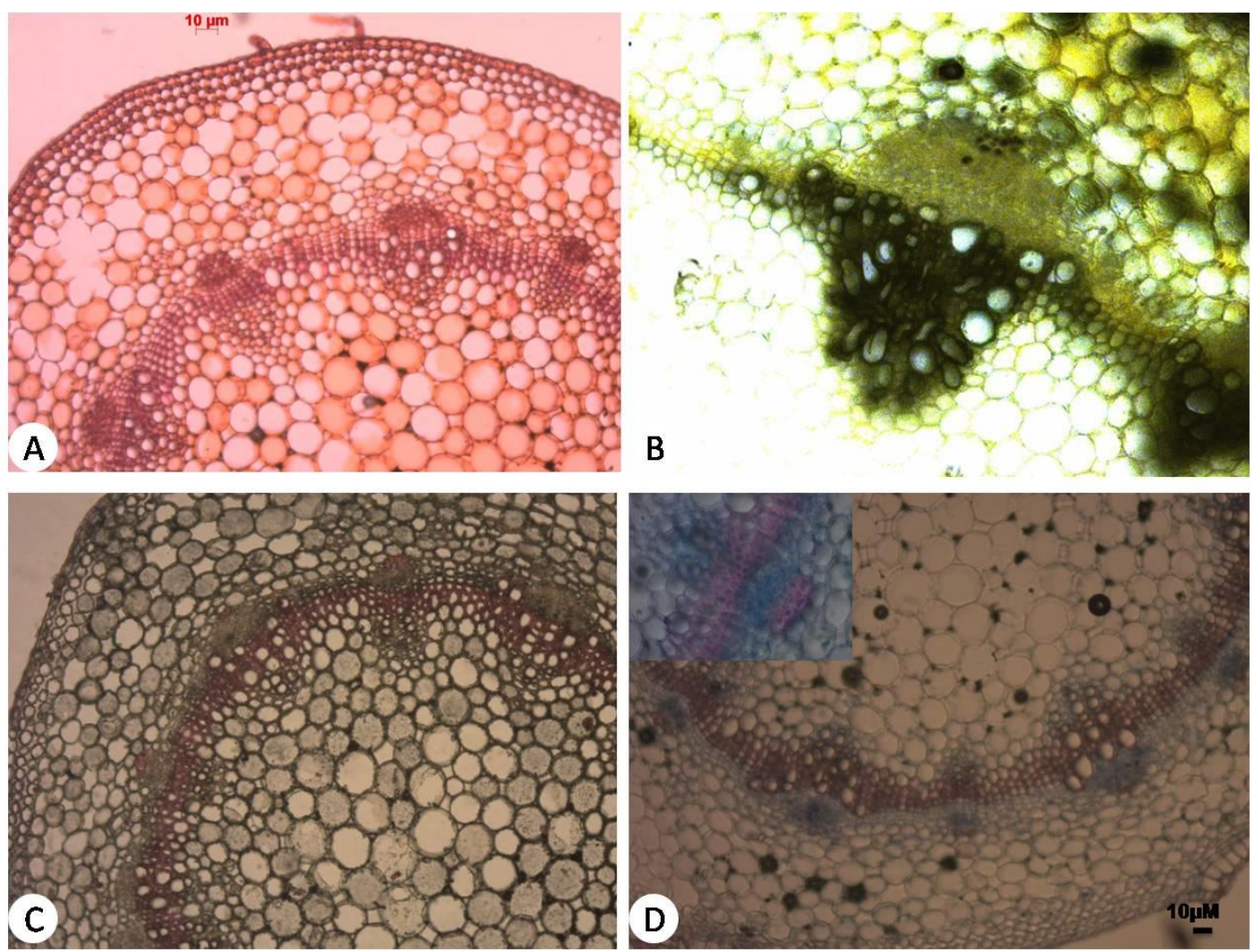

Figure 13. Histochemical localization in A. calvaA) Control section B) Localization of Starch C) Localization oflipid D) Localization of protein Scale bar $=10 \mu \mathrm{M}$ 

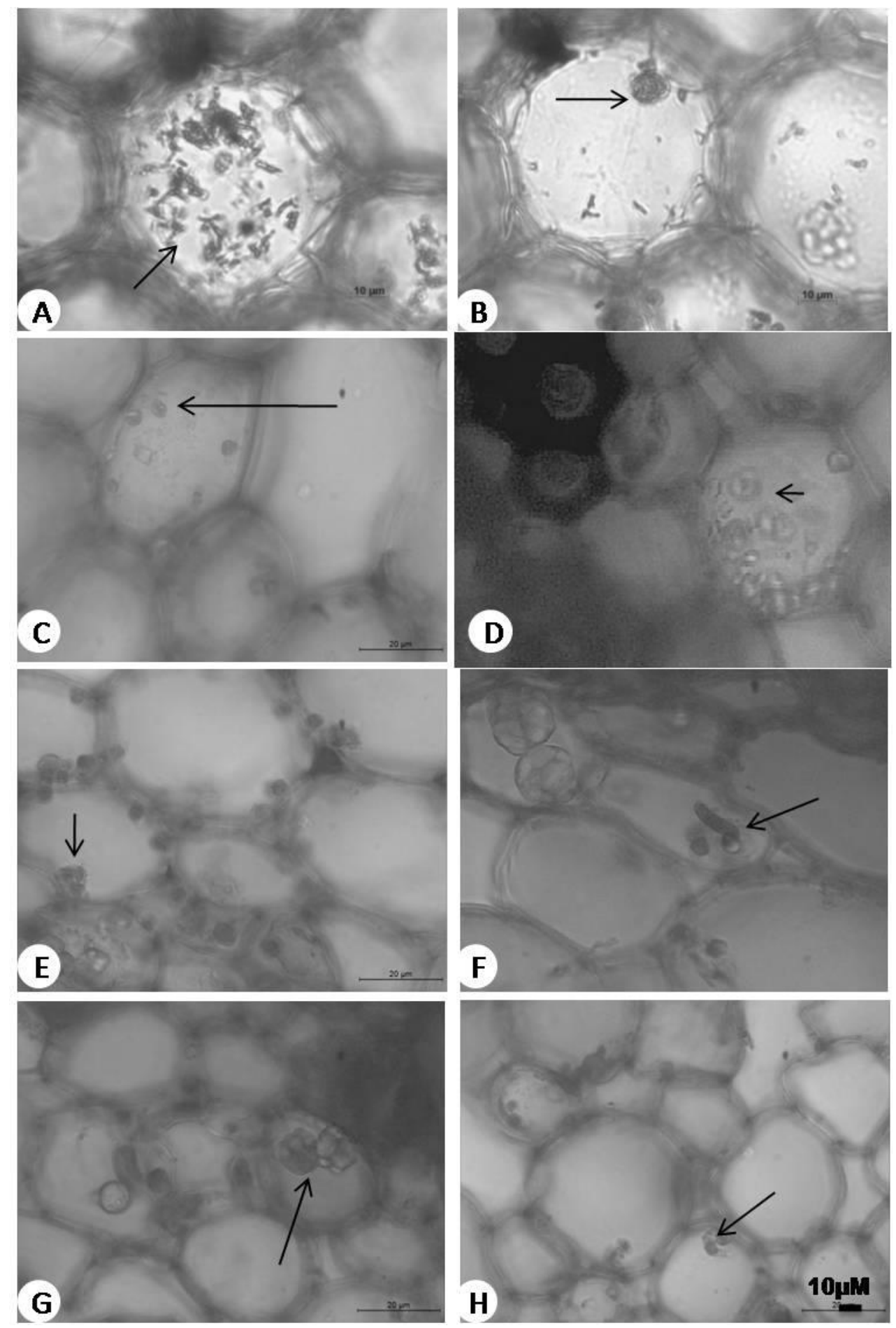

Figure 14: Calcium oxalate crystal morphotypes in Acmella A-B) Styloid crystals and druse in $A$. uliginosa C)Druses in A. calva D) Druses in $A$. vazhachalensis E) Druses in $A$. ciliata $\mathrm{F}$ ) Druses and styloid in A. tetralobata G) Druses in A. ghoshinis H) Druses and styloid in A. radicans Scale bar=10 $\mu \mathrm{M}$

\section{DISCUSSION}

The present study was conducted to introduce an internal description of leaves, petioles, peduncles, stems and roots of nine taxa of Acmella to determine its taxonomic importance and clarity the interrelationships among the present members of Acmella. In the stem anatomy the number of collenchymatous layers and packing of parenchymatous cortical layers which differ among the species. Three types of cortex were seen; loosely arranged parenchymatous, tightly arranged parenchymatous and aerenchymatous. It is well known that the average numbers of collenchymatous tissue in plants are important in comparative anatomical 
studies [21]. A. ghoshinis shows bicollateral vascular bundles where as others showed collateral bascular bundles. It is a major anatomical diagnosing feature that differentiates $A$. ghoshinis from others. In the present study, it was noticed that the number of collenchyma layer beneath the epidermis differs from species to species. The number of hypodermal collenchymatous layers and the arrangement of parenchymatous cortex together place an important role in the identification of Acmella.

Regarding the root anatomy, difference noticed in the arrangement of xylem vessels. In $A$. tetralobata it was arranged in pentarch fashion while all others possess tetrarch arrangement. In this study, mesophyll differentiated into palisade and spongy parenchyma. But there were some distinct differences among the investigated taxa by means of other foliar peculiarities such as width of the palisade tissue beneath the upper epidermis, average number of epidermal cells in the lower and upper surfaces, average number of stomata on upper surface, shape of the adaxial side and the arrangement of vascular bundles. The vascular bundles of the midrib region were accompanied by sclerenchymatous or collenchymatous tissue occupying the whole space between the bundle and upper and lower epidermis.

Petiole is of considerable taxonomic significance since its structure appears to be least affected by environmental changes. But petiole anatomy doesn't show significant role among the species of Acmella. These findings are in accordance with the information described by Metcalfe and Chalk [22] for Asteraceae. Peduncle anatomical features were similar in all the species observed. Leaf epidermal sections possess trichomes having unicellular with tapering end and multicellular without tapering end. Multicellular trichomes with tapering end were observed in petiolar sections and unicellular trichomes without tapering end were noticed in root hairs. The surface of leaves in all the species possesses non-glandular trichomes but the frequency and the trichome length varies in the intra- and interspecific level. Petiole possessed long pointed non- glandular unicellular trichomes in all the species. Peduncle had multicellular and unicellular non-glandular trichomes in each species. All the species possessed multicellular non-glandular trichomes in the stem surface. Involucres and ray florets bear unicellular trichomes [23]. All the above types of trichomes were common in Asteraceae family [24].

The secretary products include nectar, enzymes and coloring matter. Proteins, fats and oils, and carbohydrates represent reserve materials. Excretory products represent alkaloids, tannins, resins, latex, volatile oils and mineral crystals. Non-living inclusions are classified as ergastic substances, represent waste products, which are solid and secondary. Secondary products are alkaloids, glycosides, tannins, volatile oil, resins, gums and mucilage and solid products include calcium oxalate, calcium carbonate, hesperidin, diosmin and silica. Ergastic substances are products of metabolism the examples being, carbohydrates proteins, fats, tannins and various types of crystals [25].

Various types of calcium oxalate crystals exist in the form of prisms, acicular, raphides, clusters, rosettes etc. The shape of crystals may be cuboidal, rhomboidal, octahedral or elongated. Elongated crystals when massive and solitary are known as styloids.. When they are compound and cluttered in spherical masses they are called as druses. Small prismatic crystals as well as minute crystals are known as crystal sand. In our study only druses and styloids were noticed in some species [26]. Special crystal containing cells are called idioblasts, which are cells that differ distinctly from surrounding cells in both shape and structure. In Acmella idioblast cells filled with oils and tannins. Ergastic crystals and related substances have well defined economic importance that includes protective, defensive and remedial properties. Applying ergastic substances in taxonomic consideration can be of considerable importance for review of existing taxonomic delimitation for clearer circumscription and evolutionary history of the taxa [27].

Secretory structures are widely distributed in species of Asteraceae [28] and it is related to the cortex or vascular system for different members of Asteraceae [29]. Present study also showed that secretory ducts are frequently observed in cortex. The idioblast of calcium oxalate crystals are located mostly in the vascular bundles of stem and leaves which supports the suggestion that the formation of calcium oxalate crystals in plants may also be linked to the evaporation of water. The occurrence of reservoirs of chemical substances like terpenoids and alkaloids distributed along various tissues, and defined them as constitutive chemical defences, protecting the phloem nutrients against the use by organisms such as herbivores were reported [30].

The importance of secretory canals near the phloem, with the function in transportation of photo-assimilates were also pointed out [31]. The presence of secretory compounds in Acmella can be related to the plant defence system [32]. The anatomical characters of Acmella were in concordance with the general aspects of Asteraceae. All the cellular inclusions observed in the genus propose the chemical nature 
contributing the peculiar properties of the genus. The present study provides a tool for the microscopic identification of the genus and it enables the recognition of the genera.

\section{CONCLUSION}

In the present study, it was noticed that the number of collenchyma layer beneath the epidermis differs from species to species. The number of hypodermal collenchymatous layers and the arrangement of parenchymatous cortex together place an important role in the identification of Acmella. A. ghoshinis shows bicollateral vascular bundles where as others showed collateral bascular bundles. It is a major anatomical diagnosing feature that differentiates $A$. ghoshinis from others. No significant differences were noticed in the petiolar and peduncle anatomy within the species except in the number of cortical layers and vascular bundles. All the species possessed anomocytic, anisocytic and diacytic types of stomata in both adaxial and abaxial surfaces. In case of root anatomy xylem was exarch and show pentarch xylem in $A$. tetralobata while it was tetrarch in rest of the species. Histochemistry also revealed the presence of some ergastic substances such as Calcium oxalate crystals in the form of druses and styloid crystals. Secretory idioblast cells, secretory canals, lipid bodies, starch grains, oil granules and protein bodies were observed in all the studied species. Thus the anatomy along with histochemisty aids the proper identification of individual species among the taxa.

Funding: "This research was funded by Kerala State Council for Science, Technology and Environment (KSCSTE), grant number 011-20/FSHP/2011/CSTE".

Acknowledgments:The first author thanks Kerala State Council for Science, Technology and Environment (KSCSTE), Government of Kerala, Thiruvananthapuram, India for the financial support.

Conflicts of Interest: "The authors declare no conflict of interest." "The funders had no role in the design of the study; in the collection, analyses, or interpretation of data; in the writing of the manuscript, or in the decision to publish the results".

\section{REFERENCES}

1. Metcalfe CR, Chalk L. Anatomy of the Dicotyledons. Vols. 1 and 2. Oxford Publishers, U.K: 1950.

2. Rahman AHMM. Systematic studies on Asteraceae in the northern region of Bangladesh. AJLS 2013;1(4): 155-164.

3. Ozorgucu B, Gemici Y, Turkan I. Comparative Plant Anatomy. EGE JFS. 1991; 129.

4. Lersten NR, Curtis JD. Idioblasts and other unusual internal foliar secretory structures in Scrophulariaceae. Plant Syst Evol. 2001, 227(1), 63-73.

5. Makbul S, Coskuncelebi K, Turkmen, Beyazoglu O. Comparison of foliar anatomy of Scorzonera L. (Asteraceae) taxa from northeast Anatolia. Pak J Bot. 2011; 43: 135-155.

6. Milan P, Hayashi AH, Appezzato-da-Gloria B. Comparative leaf morphology and anatomy of three Asteraceae species. Braz Arch Biol Technol. 2006; 49(1): 135-144.

7. Sheela D. Histo morphological and palynological investigation on some south Indian representatives of the tribe Heliantheae - Compositae. PhD thesis, MG University. Kottayam, Kerala. 1994.

8. Jansen RK. Systematics of Spilanthes (Compositae: Heliantheae). Syst Bot Monogr. 1981; 231-257.

9. Barthlott W. Epidermal seed surface characters of plants: systematic applicability and some evolutionary aspects. Nord J Bot. 1981; 1: 345-355.

10. Reshmi GR, Rajalakshmi R. A new variety of Acmella uliginosa (Asteraceae) from Kerala, India. Int J Botany Stud. 2016; 1(3): 11-13.

11. Smith AM. Starch and starch granules. Life Sci. 2010; 3: 123.

12. Karuna Kanta Das, A. new distributional record of Acmella ciliata (Kunth) Cassini [Asteraceae] from Assam, India. Pleione 2013; 7(1): 258 - 261. 2013.

13. Reshmi, GR, Rajalakshmi R. Spilanthes tetralobata sp. nov. (Asteraceae): A new species from Kerala, India. IJAR. 2014; 2(11): 1092-1097.

14. Leng TC, Ping NS, Lim BP, Keng CL. Detection of bioactive compounds from Spilanthes acmella (L.) plants and its various in vitro culture products. J Med Plants Res. 2011; 5(3): 371-378. 
15. Sahu J, Jain K, Jain B, Sahu RK. A review on phytopharmacology and micropropagation of Spilanthes acmella. Pharmacology online. 2011; 2: 1105-1110.

16. Reshmi GR, Rajalakshmi R. Three new combinations in Acmella (Asteraceae: Heliantheae). Tropical Plant Research, An International. 2016; 3(1): 67-69.

17. O'Brien TP, McCully ME. The study of plant structure principles and selected methods (No. 581.4 O2). 1981.

18. Johansen DA. Plant microtechique. McGraw-Hill Book Company, Inc.; London. 1940.

19. Mazia D, Brewer PA, Alfert M. The cytochemical staining and measurement of protein with mercuric bromphenol blue. The Biological Bulletin. 1953; 104 (1), 57-67.

20. Ruthman, A. In Methods in CeZI Research, p. 148. Ithaca, New York: Cornell University Press. 1970.

21. Ozorgucu B, Gemici Y, Turkan I. Comparative Plant Anatomy. İzmir: Ege University Faculty of Science Publication. 1991.

22. Metcalfe CR. Anatomy of the monocotyledons. Gramineae.1 . Oxford University Press, London. 1960. 731p.

23. Reshmi GR, Rajalakshmi R. Comparative epidermal and trichome analysis in the genus Acmella. I3 Biodiversity. 2019; 5: 501.

24. Krak K, Mraz P. Trichomes in the tribe Lactuceae (Asteraceae)—taxonomic implications. Biologia. 2008; 63(5): 616-630.

25. Esau K. Plant Anatomy. Fifth edition. Wiley Eastern Reprint. 1985.

26. Fahn A. Plant Anatomy. Oxford, Mew York: Pergamon Press; 1990.

27. Idu M, Onyibe HI. Nature of ergastic substances in some Poaceae seeds. African Journal of Biotech.2011; 10(48): 9800-9803.

28. Metcalfe CR, Chalk L. Anatomy of the Dicotyledons. v. 1: Systematic anatomy of leaf and stem; with a brief history of the subject. v. 2: Wood structure and conclusion of the general introduction. Claredon Press, Oxford. 1979.

29. Budel JM, Duarte MR, Doll-Boscardin PM, Farago PV, Matzenbacher NI, Sartoratto A, et al. Composition of essential oils and secretory structures of Baccharisanomala, $B$. megapotamica and $B$. ochracea. J Essent Oil Res. 2012; 24(1): 19-24.

30. Franceschi VR, Nakata PA. Calcium oxalate in plants: formation and function. Annu Rev Plant Biol.2005; 56: 41-71.

31. Williams BC. Observations on intercellular canals in root tips with special reference to the Compositae. Am J Bot. 1954; 104-106.

32. Fahn A. Secretory tissues in plants. Academic Press. 1979.

cC (7) (8) 2020 by the authors. Submitted for possible open access publication under the terms and conditions of the Creative Commons Attribution (CC BY NC) license (https://creativecommons.org/licenses/by-nc/4.0/). 